\title{
What is Movement?
}

\author{
Nikos C. Apostolopoulos* \\ Faculty of Kinesiology and Physical Education, University of Toronto, 55 Harbord Street, Toronto, ON, M5S 2W6
}

Corresponding Author: Nikos C. Apostolopoulos, E-mail: nikos.apostolopoulos@utoronto.ca

\section{ARTICLE INFO}

\section{Article history}

Received: November 17, 2018

Accepted: December 25, 2018

Published: January 31, 2019

Volume: 7 Issue: 1

Conflicts of interest: None

Funding: None

\begin{abstract}
On the basis of their corporeity humans are not only beings of distance but also the beings of proximity, rooted beings, not only inner worldly but also beings in the world (Patocka, 1998)

Over the centuries the dialectical confluence of metaphysics and epistemology has been at the forefront in the attempt to define the concept of what it is to be human and ultimately human existence. The union of several aspects conceived from these two opposite elements has been responsible for the genesis of numerous philosophical terms and ideas such as: rationalism, materialism, socialism and idealism. Although these terms reference something different, what is primarily at the core has been the endeavour to analyse and demonstrate that it is through man's relationship with nature that one garners the understanding of self. Human consciousness in conjunction with a spatio-temporal perception, defined as movement through the time-space continuum, creates the condition where the possibility of defining the essence of existence may blossom. In this commentary, an effort is made to present movement, specifically its relationship to the "body" as the physical construct for the meaning of self.
\end{abstract}

Key words: Movement, Body, Existence, Self, Being, Metaphysics, Epistemology, Empiricism

\section{INTRODUCTION}

The human body is a multidimensional, dynamically plastic, and many of times an open-ended affair therefore, approaching it as a singular entity is a non-starter. Movement is but one of the many processes defining the body and ultimately the human being from a spatiotemporal viewpoint. It is central to life and is understood to be similar to an individual's perception comparable to the understanding of color, sound, light, and temperature. The experiences gained through movement evoke an empiricists notion, that all knowledge is based on experience thereby defining existence.

Philosophically, movement has often been described in relation to that which does not move: force, environment, and time. It is not a mechanical blundering process but a significant performance, it is a broad foundation in the whole of human existence (Van Den Berg, 1952), with the importance of the body and movement being closely related to the sense of self. In short, movement represents a means of articulating a self-understanding of oneself, possibly revealing what humans most truly 'are' (Varsamopoulou, 2007). Through perception and experience it demonstrates and defines both the harmony and discord of man and his relationship to his world, borrowing from the phenomenological Husserl notion that every cogito implies a cogitatum.

As an ontological construct the act of moving suggests the existence of self and of a type of being, since the truth of the body does not only lie in its biological usefulness, but in revealing the true nature of things through the act of motion. It is apodictic, implying both a positive evidence of "being" and the impossibility of "non-being" (Messerich O.F.M., 1953). The experiences ascertained through movement define a physical "noema". Patočka sees the body as "standing for all which lies between us and self-knowledge... and of what is true" (Varsamopoulou, 2007), suggesting that human corporeality is possibly the most important key to understanding the self, a concept that philosophy has tried to approach from the nous, the faculty of intellectual apprehension and of intuitive thought, that is, thoughtfulness. Roberts states, "exploratory maneuvers through and around an environment engender systematic profiles of sensory change that are contingent upon both the movements involved and the manner in which features of the environment are located and arranged" (Roberts, 2010). As Proust once voiced, "we have the universe but formless visions, fragmentary, and which we complete with associations of arbitrary ideas" (Proust, 1954). What is implied here is that many essential and constructive conjectures can be created if one interprets the universe through the act of movement, itself being the means of articulating the meaning of human existence, and human subjectivity.

The first-person knowledge of self, the intermingle of the person and the immediate environment from which 
experience is garnered reflects the Husserl view that the "object just is", a dictum once expressed by the German philosopher, Heidegger. Herman Schmitz claimed that all we are is body, and that this physical entity holds the key to our understanding of ourselves and everything else there is (Smith, 1962). Movement is the process integrating a propositional meaning, a direct sensory contribution, a holistic "feeling" rather than thoughts or images, for it is not simply a photographic representation of existence, but an awareness.

Through movement, the body orients one in a manner allowing for the individuation of the subject (person), enabling the ascription of thoughts and sensations relative to the subject (Carman, 1999). The body is the concrete agent of perceptual acts and it is within this perception that an understanding of oneself is formed, as having and being a body is a conscious representation of reality defined within a conceptual space (Smith, 1962). To be able to think of and invent the world around us, movement through physical exploration (i.e., tension, compression, shearing) helps in creating the collective intelligence, the gathering of possibilities, ultimately responsible for influencing thought. The importance of movement in referencing the body, in particular, the "being" was expressed by an axiom of Descartes "I am not merely present in my body, as a sailor is present in a ship, but that I am very closely joined and, as it were, intermingled with it, so that I and the body form a unit" (Cottingham, Stoothoff, \& Murdoch, 1985).

Movement enables the body to be aware, with awareness itself being the summation of tactile sensations as the body perambulates within and through its immediate environment. Referencing through movement and the changes experienced by the body are themselves immediately known, and are not informed upon reflection (Schopenhauer, 1969), suggesting that movement affords the body a cognitive-like method of "pure understanding", the establishment of an "inner sense" created from its relationship to and with the environment. Without perception, understanding would never be achieved. The concepts of cause and effect, and change, as it relates to motion, is the physical manifestation responsible for the development of cognition and subsequently the understanding of the environment, for the knowledge associated with it stands out as a perception extended in space, varying in form, and persisting through time (Schopenhauer, 1969). This knowledge is exemplified as well in the change of the properties of the body over time, a temporal development relative to and bound up with the concepts of cause, time, and motion. The unification of space and time proclaims a causality that is real relative to the subject (person), and the object (body) with the degree of acuteness of movement itself determined by the forces and the laws of nature, responsible for establishing and bringing insight. This relationship to space and time is culpable for rooting the individual to the world, creating an understanding in accordance to a stimulus. The actions of the body reveal an existence, an exposure of qualities unique to the inner mechanism of being (Schopenhauer,
1909). Every true act is an act of one's will and without exception involves a movement of the body as a means of gaining an understanding and more importantly an insight into and of an individual's quality of existence. In otherwords, knowing where we are is a necessary foundation and starting point of life. The Greek philosopher Aristotle described it as a dynamis, that each of the movements of a living being is a realisation of possibilities. Patočka stresses that the human body "does not function as a substrate, as "the basis of lived life," it does not have the character of an objective entity, it is a lived, existential corporeity (Varsamopoulou, 2007), possibly made all the more manifest through motion. In short, relating to the world through movement takes place within a matrix whose fundamental structure is always one of Self-Movement-Being.

\section{CONCLUSION}

Movement is more than just a physical act, it creates a cognitive understanding, an insight, a primary qualifying aspect of human existence through experience. In the fourth-century BC in the Confucian classic entitled Spring and Autumn Annals the following statement summarises the importance of movement:

"Flowing water never stagnates, and the hinges of an active door never rust. This is due to movement. The same principle applies to essence and energy. If the body does not move, essence does not flow. When essence does not flow, energy stagnates. " (Reid, 1994)P.7

In otherwords, movement allows the body to become one with life, suggestive of an integration of the internal and external environments in the process of gaining an understanding of self.

\section{CONFLICTS OF INTEREST}

The author declares no conflict of interest.

\section{REFERENCES}

Carman, T. (1999). The body in Husserl and Merleau-Ponty. Philosophical Topics, 27(2), 205-226.

Cottingham, J., Stoothoff, R., \& Murdoch, D. (1985). The philosophical writings of Descartes (trans.). Cambridge: Cambridge University Press.

de Beer, C. S. (2006). Muthos, logos, nous: In pursuit of teh ultimate human thought. Phronimon, 7(1), 55-68.

Messerich O.F.M., V. (1953). An apodictic approach to reality. Franciscan Studies, 13(2-3), 1-36.

Patocka, J. (1998). Body, Community, Language, World, trans. Erazim Kohak. Chicago: Open Court.

Proust, M. (1954). A la reserche du temps perdu. A l'ombre des jeune filles en fleurs. Paris: Gallimard.

Reid, D. P. (1994). The complete book of Chinese health and healing - Guarding the three treasures. Boston: Shambala Publications Inc.

Roberts, T. (2010). Understanding 'sensorimotor understanding’. Phenom Cogn Sci, 9, 101-111. 
Schopenhauer, A. (1909). The world as will and idea (trans. from the German by Haldane, R.B. \& Kemp, J.). London: Kegan Paul, Trench, Trubner \& Co.

Schopenhauer, A. (1969). The world as will and representation (trans. from the German by Payne, E.F.J.). New York: Dover Publications, Inc.

Smith, C. (1962). Maurice Merleau-Ponty, Phenomenology of Perception, trans. London: Roiutledge \& Kegan Paul.
Van Den Berg, J. H. (1952). The human body and the significance of human movements: A phenomenological study. Philosophy and Phenomenological Research, 13(2), 159-183.

Varsamopoulou, E. (2007). Three movements of life: Jan Patocka's philosophy of personal being. The European Legacy, 12(5), 577-588. 